Correspondence

Lyudmila A. Romanenko Iro@piboc.dvo.ru

\section{Sphingomonas molluscorum sp. nov., a novel marine isolate with antimicrobial activity}

\author{
Lyudmila A. Romanenko, ${ }^{1}$ Masataka Uchino, ${ }^{2}$ Galina M. Frolova, ${ }^{1}$ \\ Naoto Tanaka, ${ }^{3}$ Natalia I. Kalinovskaya, ${ }^{1}$ Nicolai Latyshev $^{4}$ \\ and Valery V. Mikhailov ${ }^{1}$
}
${ }^{1}$ Pacific Institute of Bioorganic Chemistry, Far-Eastern Branch, Russian Academy of Sciences, Prospect 100 Let Vladivostoku 159, 690022 Vladivostok, Russia
${ }^{2}$ Tokyo University of Agriculture, Department of Applied Biology and Chemistry, Faculty of Applied Bioscience, Laboratory of Food Science and Technology, Sakuragaoka 1-1-1, Setagaya-ku, Tokyo 156-8502, Japan
${ }^{3}$ Department of Medical and Life Science, Faculty of Pharmaceutical Science, Tokyo University of Science, 2641 Yamazaki, Noda, Chiba 278-8510, Japan
${ }^{4}$ Institute of Marine Biology, Far-Eastern Branch, Russian Academy of Sciences, 690041 Vladivostok, Russia

An aerobic, Gram-negative, yellow-pigmented, non-motile bacterium, designated strain KMM $3882^{\top}$, was isolated from a marine bivalve (Anadara broughtoni) collected from Peter the Great Bay, Sea of Japan, and was subjected to phenotypic and phylogenetic analyses. Strain KMM $3882^{\top}$ was found to exert a remarkable inhibitory activity against a number of Gram-positive micro-organisms.

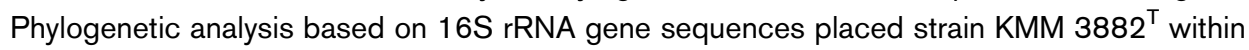
the genus Sphingomonas, as an independent lineage adjacent to Sphingomonas dokdonensis DS- $4^{\top}$ and Sphingomonas panni DSM $15761^{\top}$. Strain KMM $3882^{\top}$ showed the highest $16 \mathrm{~S}$ rRNA gene sequence similarity to Sphingomonas dokdonensis DS-4 ${ }^{\top}$ (97.3\%); similarities of 96.5-96.7\% were obtained with Sphingomonas pituitosa DSM $13101^{\top}$, Sphingomonas azotifigens NBRC $15497^{\top}$, Sphingomonas asaccharolytica NBRC $15499^{\top}$, Sphingomonas trueperi DSM $7225^{\top}$ and Sphingomonas panni DSM $15761^{\top}$. Chemotaxonomically, strain KMM $3882^{\top}$ contained sphingoglycolipid, $\mathrm{C}_{16: 0}$ and $\mathrm{C}_{18: 1}$ as predominant fatty acids and 2-OH $\mathrm{C}_{14: 0}$ as a major 2-hydroxy fatty acid, confirming the affiliation of strain $\mathrm{KMM} 3882^{\top}$ with the genus Sphingomonas. On the basis of phylogenetic analysis, DNA-DNA hybridization and physiological and biochemical characterization, strain $\mathrm{KMM} 3882^{\top}$ should be classified as representing a novel species of the genus Sphingomonas, for which the name Sphingomonas

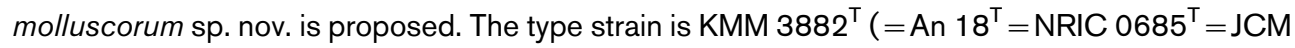
$14122^{\top}=$ CIP $109223^{\top}$ ).

\footnotetext{
Abbreviations: DPG, diphosphatidylglycerol; FAME, fatty acid methyl ester; PC, phosphatidylcholine; PDE, phosphatidyldimethylethanolamine; $\mathrm{PE}$, phosphatidylethanolamine; PG, phosphatidylglycerol; PME, phosphatidylmonomethylethanolamine; SGL, sphingoglycolipid.

The GenBank/EMBL/DDBJ accession number for the $16 \mathrm{~S}$ rRNA gene

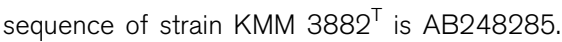

Tables detailing the antimicrobial properties of strain $\mathrm{KMM} 3882^{\top}$ and cellular fatty acid profiles of strain $\mathrm{KMM} 3882^{\top}$ and the type strains of related Sphingomonas species, and figures showing a chromatogram of the polar lipids of strain $\mathrm{KMM} 3882^{\mathrm{T}}$ and phylogenetic trees based on $16 \mathrm{~S}$ rRNA gene sequences constructed by using maximum-likelihood and maximum-parsimony are available as supplementary material in IJSEM Online.
}

The genus Sphingomonas was created by Yabuuchi et al. (1990) and emended subsequently by Takeuchi et al. (2001), Yabuuchi et al. (2002) and Busse et al. (2003). According to Busse et al. (2003), Sphingomonas species comprising cluster I proposed by Takeuchi et al. (2001) should be considered as Sphingomonas sensu stricto, including the type species Sphingomonas paucimobilis.

During the screening of mollusc isolates for antimicrobial activity, strain KMM $3882^{\mathrm{T}}$ was found to have antagonistic effects against a range of Gram-positive indicator bacteria and yeast, but not Gram-negative or fungal cultures. A butanol extract of cellular biomass of strain $\mathrm{KMM} 3882^{\mathrm{T}}$ was 
found to have antimicrobial properties against Grampositive cocci and bacilli (see Supplementary Table S1 in IJSEM Online), pointing to low-molecular-weight metabolites, which could be responsible for the antagonistic activity. Phylogenetic analysis based on 16S rRNA gene sequences demonstrated that strain KMM $3882^{\mathrm{T}}$ belongs to the genus Sphingomonas and may represent a novel species of this genus. Some sphingomonads have been reported to produce the anticyanobacterial compounds argimicins (Yamaguchi et al., 2003) or to be antagonists of phytopathogenic fungi (Berg \& Balin, 1994). It should be noted that much more is known about the ability of Sphingomonas strains to degrade organic substances or pollutants, and their biosynthetic production of extracellular polymers (Denner et al., 2001; Balkwill et al., 2003). In the present study, we report the polyphasic characterization of strain KMM $3882^{\mathrm{T}}$, which was isolated from a marine mollusc, Anadara broughtoni. On the basis of the phenotypic and molecular data obtained, Sphingomonas molluscorum sp. nov. is described.

Strain KMM $3882^{\mathrm{T}}$ was isolated from a marine bivalve specimen (Anadara broughtoni Schrenck 1867), collected from Peter the Great Bay, the Sea of Japan, Russia, in June 2003. The mollusc specimen was carefully rinsed with sterile seawater and cut aseptically with a scalpel. An aliquot of intervalve blood liquor was spread on agar plates of seawater medium (SWM), containing $\left(\mathrm{l}^{-1}\right): 5.0 \mathrm{~g}$ peptone, $2.5 \mathrm{~g}$ yeast extract, $1.0 \mathrm{~g}$ glucose, $0.2 \mathrm{~g} \mathrm{~K}_{2} \mathrm{HPO}_{4}, 0.05 \mathrm{~g} \mathrm{MgSO}$ and $15.0 \mathrm{~g}$ agar in $750 \mathrm{ml}$ seawater $/ 250 \mathrm{ml}$ distilled water. The plates were incubated for 14 days at $28^{\circ} \mathrm{C}$. Strain KMM $3882^{\mathrm{T}}$ grew aerobically on tryptic soy agar (TSA), marine agar 2216 and marine broth (all from Difco) at $28^{\circ} \mathrm{C}$. Strain $\mathrm{KMM} 3882^{\mathrm{T}}$ was stored at $-80{ }^{\circ} \mathrm{C}$ in marine broth supplemented with $30 \%(\mathrm{v} / \mathrm{v})$ glycerol. Motility was observed by using the hanging drop method. Cell morphology was examined by scanning electron microscopy of exponential phase cells grown in SWM. The Gramreaction, oxidase and catalase reactions, production of $\mathrm{H}_{2} \mathrm{~S}$ and indole, and hydrolysis of casein, gelatin, starch, chitin, Tween 80, Tween 40 and Tween 20 were tested according to methods described by Smibert \& Krieg (1994). The oxidation-fermentation medium of Leifson (1963) was used to test acid production from carbohydrates, with $1 \%$ $(\mathrm{w} / \mathrm{v})$ of each compound being used. Growth at various temperatures, $\mathrm{pH}$ values and salinities, and substrate utilization were studied as described previously (Romanenko et al., 2003, 2005). In addition, biochemical tests were carried out using API 20NE test kits (bioMérieux), as described by the manufacturer. API test results were read after $24 \mathrm{~h}$ and 2 days of incubation at $28^{\circ} \mathrm{C}$.

For fatty acid analysis, strain KMM $3882^{\mathrm{T}}$ was grown on TSA at $28^{\circ} \mathrm{C}$ for $48 \mathrm{~h}$. Fatty acid methyl esters (FAMEs) were obtained by using mild alkaline or acid methanolysis, as described by Rowe et al. (2000). The FAMEs were extracted with hexane and analysed by using a GLC-MS Hewlett Packard model 6890 gas chromatograph equipped with an
HP 5 MS $5 \%$ Phenyl Methyl Siloxane capillary column $(30 \mathrm{~m} \times 250 \mu \mathrm{m} \times 0.25 \mu \mathrm{m})$, connected to a Hewlett Packard model 5973 mass spectrometer. Identification of the FAMEs was accomplished by using equivalent chainlength values, comparing the retention times of the samples to those of standards. Lipids were extracted by using the chloroform/methanol extraction method of Bligh \& Dyer (1959). The polar lipid composition was determined as described by Denner et al. (2001). Yellow pigments were tested by using TLC (chloroform/methanol, $5: 3, \mathrm{v} / \mathrm{v}$ ). The visible spectrum of the acetone extract was examined with a CECIL 7250 spectrophotometer.

To investigate the production of antimicrobial compounds, strain KMM $3882^{\mathrm{T}}$ was cultivated for $48 \mathrm{~h}$ at $28^{\circ} \mathrm{C}$ on agar slants of SWM supplemented with $0.2 \%(\mathrm{w} / \mathrm{v})$ casein hydrolysate. The cells were harvested, suspended in distilled water and subjected to ultrasound for 2 min. The suspension obtained was extracted twice with equal volumes of $n$ butanol. The organic layers were evaporated to dryness and the residue was diluted in an appropriate amount of ethanol and centrifuged to remove insoluble substances. The cellular extract obtained, referred to as butanol extract, was examined for the presence of antimicrobial activity by using the agar diffusion method. To test for antimicrobial activity, $100 \mu \mathrm{l}$ butanol extract $(100 \mu \mathrm{g} / 100 \mu \mathrm{l}$, in $10 \%$ ethanol) was placed in wells (9 $\mathrm{mm}$ in diameter) cut in nutrient agar plates that had been inoculated with $100 \mu \mathrm{l}$ of an indicator culture suspension $\left(10^{8}\right.$ cells $\left.\mathrm{ml}^{-1}\right)$. The plates were incubated at $28^{\circ} \mathrm{C}$ for 3 days and examined daily. The formation of a clear inhibition zone around the wells was considered to be indicative of antimicrobial activity. Zones of inhibition were recorded by measuring the clear zone diameter in millimetres, including the $9 \mathrm{~mm}$ diameter of the well. All tests were performed in triplicate. The indicator strains used are listed in Supplementary Table S1 in IJSEM Online. Enterococcus faecium CIP 104105 and Staphylococcus aureus CIP $65.8^{\mathrm{T}}$ were obtained from Collection de l'Institut Pasteur (CIP), Paris, France, and the Bacillus species were obtained from the All Russian Collection of Microorganisms (VKM), Pushchino, Russia.

The DNA base composition was determined as described by Marmur \& Doty (1962) and Owen et al. (1969). DNA-DNA relatedness was measured by using the photobiotin-labelled DNA probe microplate method of Ezaki et al. (1989). The $16 \mathrm{~S}$ rRNA gene sequence (1381 bp) of strain KMM $3882^{\mathrm{T}}$ was determined and analysed as described by Shida et al. (1997). The sequence was compared with 16S rRNA gene sequences retrieved from the EMBL/GenBank/ DDBJ databases by using the FASTA program (Pearson \& Lipman, 1988). Distances were calculated according to the method of Jukes \& Cantor (1969). Sequences were aligned using the CLUSTAL W program (Thompson et al., 1994) in the InforBIO software (Sugawara et al., 2003) and putative variable regions, positions $70-100,181-219$, 447-487, 1004-1036, 1133-1141 and 1446-1456 (Escherichia coli numbering system) (Anzai et al., 2000), were eliminated. 
Phylogenetic trees were constructed by using maximumlikelihood and maximum-parsimony methods with the PHYLIP package (Felsenstein, 1989), and the neighbourjoining method of Saitou \& Nei (1987) with the CLUSTAL W program.

Cells of strain KMM $3882^{\mathrm{T}}$ were Gram-negative, aerobic, oxidase- and catalase-positive, yellow-pigmented and nonmotile. Physiological, biochemical and chemotaxonomic characteristics of strain KMM $3882^{\mathrm{T}}$ are given in Table 1, in Supplementary Table S2 and Fig. S1 available in IJSEM Online, and in the species description. The predominant polar lipids of strain KMM $3882^{\mathrm{T}}$ comprised phosphatidylcholine (PC), sphingoglycolipid (SGL), phosphatidylglycerol (PG), phosphatidylethanolamine (PE) and diphosphatidylglycerol (DPG). Phosphatidyldimethylethanolamine (PDE), aminolipid and two unknown lipids were also present as minor components (see Supplementary Fig. S1 in IJSEM Online). Two acetone-soluble pigments were found to have the following spectral characteristics: $\lambda_{\max }$ at 426 and $449 \mathrm{~nm}$ and a shoulder at $478 \mathrm{~nm}$ for the first; and $\lambda_{\max }$ at 451 and $479 \mathrm{~nm}$ and a shoulder at $426 \mathrm{~nm}$ for the second. The polar

Table 1. Phenotypic characteristics of Sphingomonas molluscorum sp. nov. and related Sphingomonas species

Taxa: 1, strain KMM $3882^{\mathrm{T}}$ (data from this study); 2, Sphingomonas pituitosa (Denner et al., 2001); 3, Sphingomonas trueperi (Kämpfer et al., 1997); 4, Sphingomonas panni (Busse et al., 2005); 5, Sphingomonas azotifigens (Xie \& Yokota, 2006); 6, Sphingomonas paucimobilis (Yabuuchi et al., 1990; Kämpfer et al., 1997). +, Positive; -, negative; W, weak reaction; V, variable reaction between strains; ND, not determined. All were positive for aesculin hydrolysis and $\beta$-galactosidase production, and negative for indole production and assimilation of phenylacetate.

\begin{tabular}{|lcccccc|}
\hline Characteristic & $\mathbf{1}$ & $\mathbf{2}$ & $\mathbf{3}$ & $\mathbf{4}$ & $\mathbf{5}$ & $\mathbf{6}$ \\
\hline Motility & - & + & + & - & + & + \\
Oxidase & + & - & + & - & + & - \\
Nitrate reduction & - & - & + & $\mathrm{ND}$ & - & - \\
Gelatin hydrolysis & - & - & + & $\mathrm{ND}$ & $\mathrm{V}$ & + \\
Starch hydrolysis & - & - & - & $\mathrm{ND}$ & + & + \\
Tween 80 & + & + & - & $\mathrm{ND}$ & + & + \\
Assimilation of: & & & & & & \\
D-Glucose & + & + & + & - & + & + \\
L-Arabinose & + & + & + & - & + & + \\
D-Mannose & + & - & + & $\mathrm{W}$ & $\mathrm{ND}$ & + \\
Maltose & + & + & + & $\mathrm{W}$ & + & + \\
$\quad$ N-Acetylglucosamine & + & + & + & - & $\mathrm{ND}$ & + \\
D-Gluconate & + & + & - & - & - & - \\
Caprate & - & + & - & $\mathrm{ND}$ & $\mathrm{ND}$ & - \\
Adipate & - & + & - & - & - & - \\
L-Malate & - & + & + & + & + & + \\
Citrate & - & - & - & + & - & - \\
DNA G+C content & 68.3 & 64.5 & 65.6 & $\mathrm{ND}$ & $66.0-68.0$ & 63.7 \\
(mol\%) & & & & & & \\
& & & & & & \\
& & & & & &
\end{tabular}

lipid composition of strain $\mathrm{KMM} 3882^{\mathrm{T}}$ was consistent in its major components, PC, SGL, PG, PE and DPG, with those reported for the closely related species, Sphingomonas trueperi (Kämpfer et al., 1997), Sphingomonas paucimobilis (Kämpfer et al., 1997) and Sphingomonas panni (Busse et al., 2005). Denner et al. (2001) reported for Sphingomonas pituitosa the presence of DPG, PE, PDE, PG, SGL and an unidentified polar lipid as major components and $\mathrm{PC}$, phosphatidylmonomethylethanolamine (PME), aminophospholipid, unknown phospholipids and an unknown glycoplipid as minor components. Strain KMM $3882^{\mathrm{T}}$ could be distinguished from the above-mentioned species and from other recognized Sphingomonas species (Kämpfer et al., 1997; Denner et al., 2001; Busse et al., 2003) by the presence of the minor polar lipid components of unknown lipids and aminolipid and the absence of PME and glycolipids.

The fatty acid profile of strain KMM $3882^{\mathrm{T}}$ was characterized by the occurrence of $\mathrm{C}_{16: 0}$ and $\mathrm{C}_{18: 1}$ as predominant fatty acids $(58.2 \%), 2-\mathrm{OH} \mathrm{C}_{14: 0}(12.8 \%)$ as a major 2hydroxy fatty acid and the absence of 3-hydroxy fatty acids. The fatty acid composition is given in more detail in the species description and in Supplementary Table S2 available in IJSEM Online. The cellular fatty acid profile of strain KMM $3882^{\mathrm{T}}$ differed from those of the type strains of related Sphingomonas species by the presence of $\mathrm{C}_{18: 2 \omega 6}(8.1 \%)$, $\mathrm{C}_{19: 1}(3.9 \%), \mathrm{C}_{15: 1}(1.6 \%)$ and the abundance of $\mathrm{C}_{18: 0}$ $(9.2 \%)$. The latter fatty acid was present only in S. azotifigens NBRC $15497^{\mathrm{T}}$ (3.8\%; Xie \& Yokota, 2006). Unlike Sphingomonas pituitosa DSM $13101^{\mathrm{T}}$ and Sphingomonas azotifigens NBRC $15497^{\mathrm{T}}$, strain $\mathrm{KMM} 3882^{\mathrm{T}}$ did not contain 2-OH C $15: 0$. The chemotaxonomic features of strain KMM $3882^{\mathrm{T}}$, including the presence of sphingoglycolipid, $\mathrm{C}_{16: 0}, \mathrm{C}_{18: 1}$ and 2-OH $\mathrm{C}_{14: 0}$ as major fatty acids and the absence of 3-hydroxy fatty acids are in line with the characteristic components reported for recognized species of the genus Sphingomonas (Kämpfer et al., 1997; Takeuchi et al., 2001; Busse et al., 2003).

The DNA G $+\mathrm{C}$ content of strain KMM $3882^{\mathrm{T}}$ was $68.3 \mathrm{~mol} \%$, which is within the range of values (61.6-68.0 mol\%) reported for recognized Sphingomonas species. The value obtained is similar to those determined for recently described Sphingomonas azotifigens strains (66.0-68.0 mol\%), but is slightly higher than the values (63.7-65.6 mol\%) determined for Sphingomonas pituitosa, Sphingomonas trueperi and the type species Sphingomonas paucimobilis (Table 1).

On the basis of the morphological and physiological characteristics, polar lipid composition, fatty acid profile and the DNA G $+\mathrm{C}$ content, strain $\mathrm{KMM} 3882^{\mathrm{T}}$ can be considered to be a member of the genus Sphingomonas.

Phylogenetic analysis based on 16S rRNA gene sequences positioned strain KMM $3882^{\mathrm{T}}$ within the genus Sphingomonas as an independent lineage adjacent to Sphingomonas dokdonensis DS- $4^{\mathrm{T}}$ (Yoon et al., 2006) and Sphingomonas panni DSM $15761^{\mathrm{T}}$ (Busse et al., 2005) 
(Fig. 1). The same relationship was also evident in 16S rRNA gene sequence dendrograms based on different treeing algorithms (see Supplementary Figs S1 and S2 in IJSEM Online). Strain KMM $3882^{\mathrm{T}}$ showed the highest $16 \mathrm{~S}$ rRNA gene sequence similarity of $97.3 \%$ to Sphingomonas dokdonensis DS-4 $4^{\mathrm{T}}$; similarities of $96.5-96.7 \%$ were obtained with Sphingomonas pituitosa DSM $13101^{\mathrm{T}}$, Sphingomonas azotifigens NBRC $15497^{\mathrm{T}}$, Sphingomonas asaccharolytica NBRC $15499^{\mathrm{T}}$, Sphingomonas trueperi DSM $7225^{\mathrm{T}}$ and Sphingomonas panni DSM $15761^{\mathrm{T}}$. The $16 \mathrm{~S}$ rRNA gene sequence similarity value of $97 \%$ is consistent with the criterion for differentiation of bacteria at the species level given by Stackebrandt \& Goebel (1994). Relatively low 16S rRNA gene sequence similarity values ( $96.7 \%$ to Sphingomonas panni DSM $15761^{\mathrm{T}}, 96.6 \%$ to Sphingomonas trueperi DSM $7225^{\mathrm{T}}$ and $96.5 \%$ to Sphingomonas pituitosa DSM $13101^{\mathrm{T}}$, Sphingomonas azotifigens NBRC $15497^{\mathrm{T}}$ and Sphingomonas asaccharolytica NBRC $15499^{\mathrm{T}}$ and values below these to other Sphingomonas species) clearly demonstrated that strain $\mathrm{KMM} 3882^{\mathrm{T}}$ could be regarded as representing a novel species within the genus Sphingomonas.

The level of DNA-DNA relatedness for strain KMM $3882^{\mathrm{T}}$ and Sphingomonas dokdonensis DS- $4^{\mathrm{T}}$ was determined, because of their 16S rRNA gene sequence similarity of $97.3 \%$. The DNA-DNA relatedness of $28 \%$ determined for strain KMM $3882^{\mathrm{T}}$ and Sphingomonas dokdonensis DS- $\mathrm{T}^{\mathrm{T}}$ was significantly less than $70 \%$, indicating that these strains belong to separate species (Wayne et al., 1987).

The phylogenetic distinction of strain KMM $3882^{\mathrm{T}}$ was supported by its phenotypic characteristics. The phenotypic features of strain KMM $3882^{\mathrm{T}}$ and phylogenetically related species are given in Table 1. Sphingomonas dokdonensis
DS- $4^{\mathrm{T}}$ was not included because of its recent description (Yoon et al., 2006). Strain KMM $3882^{\mathrm{T}}$ could be distinguished from its close relatives by a combination of phenotypic features. Strain KMM $3882^{\mathrm{T}}$ was similar to Sphingomonas panni in being non-motile, but differed in oxidase reaction and assimilation pattern. Strain KMM $3882^{\mathrm{T}}$ was similar to Sphingomonas trueperi, Sphingomonas paucimobilis (Kämpfer et al., 1997) and Sphingomonas azotifigens (Xie \& Yokota, 2006) in being able to assimilate D-glucose, L-arabinose, maltose and $\mathrm{N}$-acetylglucosamine, but differed from all these species in being non-motile and able to assimilate D-gluconate, and from Sphingomonas trueperi and Sphingomonas paucimobilis by not being able to hydrolyse gelatin, and from Sphingomonas paucimobilis and Sphingomonas azotifigens by not being able to hydrolyse starch.

Based on the results obtained, it is proposed that strain KMM $3882^{\mathrm{T}}$ represents a novel species in the genus Sphingomonas, with the name Sphingomonas molluscorum sp. nov.

\section{Description of Sphingomonas molluscorum sp. nov.}

Sphingomonas molluscorum (mol.lus.co'rum. N.L. pl. n. Mollusca a zoological phylum; N.L. gen. pl. n. molluscorum of molluscs classified in the phylum Mollusca).

Cells are Gram-negative, non-sporing, non-motile, small rods $(0.4-0.6 \mu \mathrm{m}$ wide and $1.0-1.5 \mu \mathrm{m}$ long). Form yellowpigmented, smooth, shining and opaque colonies with regular edges, and 3-4 $\mathrm{mm}$ in diameter. Diffusible pigments are not produced. Grows at $7-37^{\circ} \mathrm{C}$, with optimum growth at $25-28^{\circ} \mathrm{C}$. Does not grow at 4 or $42^{\circ} \mathrm{C}$. Sodium ions are

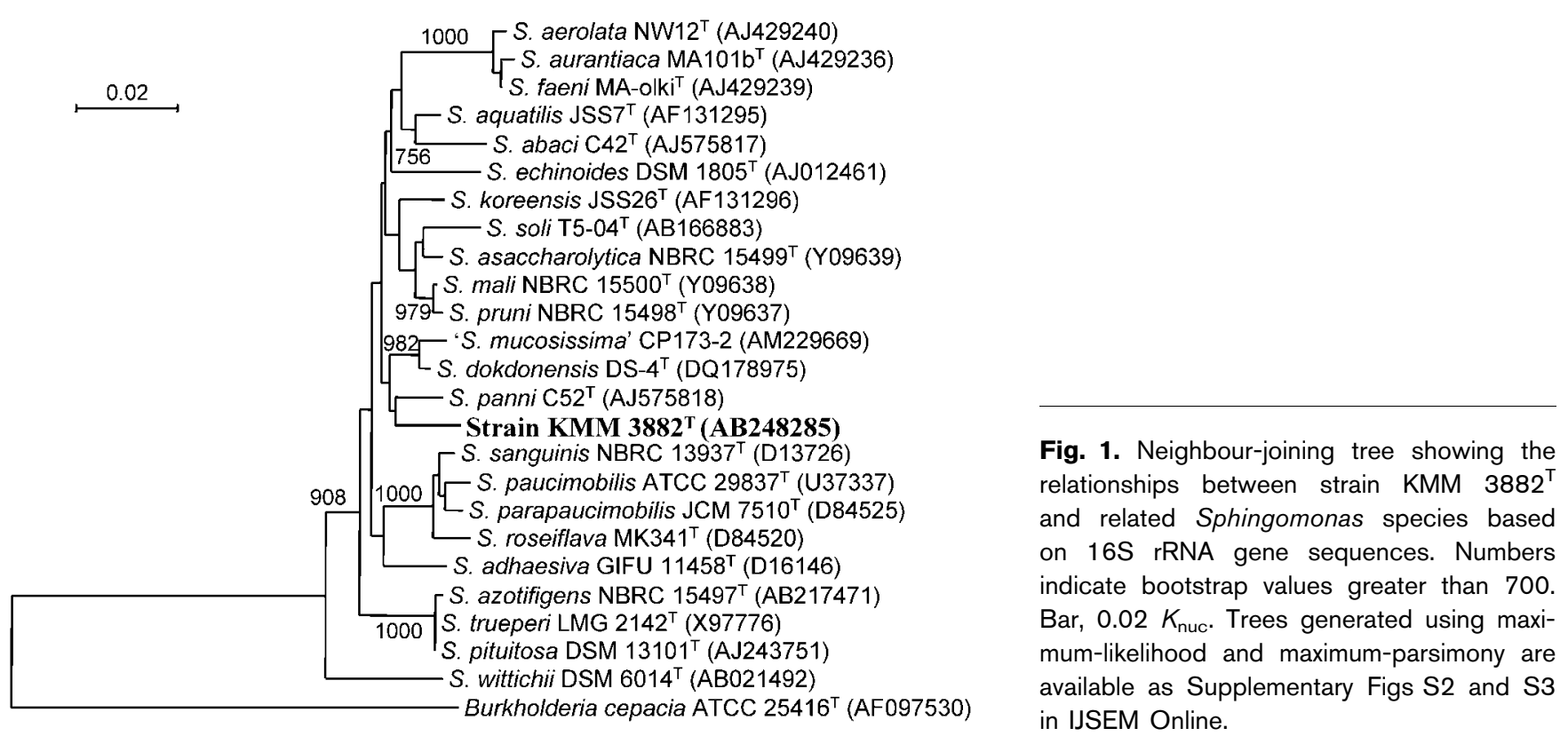


not required for growth. Grows in $0-4 \% \mathrm{NaCl}$. Oxidase-, catalase- and $\beta$-galactosidase-positive. Indole, $\mathrm{H}_{2} \mathrm{~S}$, urease, arginine dihydrolase, ornithine decarboxylase, lysine decarboxylase and phenylalanine deaminase are not produced. Casein, gelatin, starch and chitin are not hydrolysed. Hydrolysis of Tween 80, Tween 40 and Tween 20 is positive. Production of acid from arabinose, galactose and D-xylose is weakly positive. Acid is not produced from D-glucose, rhamnose, maltose, sucrose, lactose, inositol, mannitol or glycerol. Other physiological and biochemical characteristics are given in Table 1. In addition, in API tests, assimilation of mannitol is negative. According to conventional methods, nitrate reduction and utilization of sucrose, inositol, sorbitol and mannitol are negative; utilization of Dglucose, L-arabinose, lactose, D-mannose and malonate is positive. Predominant polar lipids are PC, SGL, PG, PE and DPG. PDE, aminolipid and two unknown lipids are present as minor components. Two acetone-soluble pigments are characterized by $\lambda_{\max }$ at 426 and $449 \mathrm{~nm}$ and a shoulder at $478 \mathrm{~nm}$, and $\lambda_{\max }$ at 451 and $479 \mathrm{~nm}$ and a shoulder at $426 \mathrm{~nm}$. Contains $\mathrm{C}_{16: 0}(24.0 \%), \mathrm{C}_{18: 1} \omega 9(16.5 \%)$ and $\mathrm{C}_{18: 1} \omega 7 c(17.7 \%)$ as major fatty acids and $2-\mathrm{OH} \mathrm{C}_{14: 0}$ $(12.8 \%)$ as a major 2-hydroxy fatty acid; $\mathrm{C}_{15: 0}(1.7 \%)$; $\mathrm{C}_{15: 1}(1.6 \%), \mathrm{C}_{16: 1}(2.1 \%), \mathrm{C}_{17: 1}(2.5 \%), \mathrm{C}_{18: 2 \omega 6}(8.1 \%)$, $\mathrm{C}_{18: 0}(9.2 \%)$ and $\mathrm{C}_{19: 1}(3.9 \%)$ are also present.

The DNA G + C content of the type strain is $68.3 \mathrm{~mol} \%$ (determined by using the thermal denaturation method). The type strain is $\mathrm{KMM} 3882^{\mathrm{T}} \quad\left(=\mathrm{An} \quad 18^{\mathrm{T}}=\mathrm{NRIC}\right.$ $0685^{\mathrm{T}}=\mathrm{JCM} 14122^{\mathrm{T}}=$ CIP $\left.109223^{\mathrm{T}}\right)$, which was isolated from a marine bivalve (Anadara broughtoni), collected from Peter the Great Bay, The Sea of Japan, Russia.

\section{Acknowledgements}

We would like to thank Dr Jung-Hoon Yoon, Korean Research Institute of Bioscience and Biotechnology, KRIBB, Taejon, Korea, for providing Sphingomonas dokdonensis DS- $4^{\mathrm{T}}$ for DNA-DNA hybridization experiments, Dr Chantal Bizet, Collection de l'Institut Pasteur, Institut Pasteur (CIP), Paris, France, for the gift of indicator strains and Miss Rei Suzuki for her technical assistance. This study was supported by grant no. 06-04-96007 from the Russian Foundation for Basic Research (RFBR) and Far-Eastern Branch of Russian Academy of Sciences, grant no. 06-04-48578 from RFBR and by grants from Rosnauka KMM and Scientific Schools.

\section{References}

Anzai, Y., Kim, H., Park, J.-Y., Wakabayashi, H. \& Oyaizu, H. (2000). Phylogenetic affiliation of the pseudomonads based on 16S rRNA sequence. Int J Syst Evol Microbiol 50, 1563-1589.

Balkwill, D. L., Fredrickson, J. K. \& Romine, M. F. (2003). Sphingomonas and related genera. In The Prokaryotes: An Evolving Electronic Resource for the Microbiological Community, 3rd edn, release 3.14. Edited by M. Dworkin, S. Falkow, E. Rosenberg, K.-H. Schleifer \& E. Stackebrandt. New York: Springer Inc.

Berg, G. \& Balin, G. (1994). Bacterial antagonists to Verticillium dahliae Kleb. J Phytopathol 141, 99-110.

Bligh, E. G. \& Dyer, W. J. (1959). A rapid method of total lipid extraction and purification. Can J Biochem Physiol 37, 911-917.
Busse, H.-J., Denner, E. B. M., Buczolits, S., Salkinoja-Salonen, M., Bennasar, A. \& Kämpfer, P. (2003). Sphingomonas aurantiaca sp. nov., Sphingomonas aerolata sp. nov. and Sphingomonas faeni sp. nov., air- and dustborne and Antarctic, orange-pigmented, psychrotolerant bacteria, and emended description of the genus Sphingomonas. Int J Syst Evol Microbiol 53, 1253-1260.

Busse, H.-J., Hauser, E. \& Kämpfer, P. (2005). Description of two novel species, Sphingomonas abaci sp. nov. and Sphingomonas panni sp. nov. Int J Syst Evol Microbiol 55, 2565-2569.

Denner, E. B. M., Paukner, S., Kämpfer, P., Moore, E. R. B., Abraham, W.-R., Busse, H.-J., Wanner, G. \& Lubitz, W. (2001). Sphingomonas pituitosa sp. nov., an exopolysaccharide-producing bacterium that secretes an unusual type of sphingan. Int J Syst Evol Microbiol 51, 827-841.

Ezaki, T., Hashimoto, Y. \& Yabuuchi, E. (1989). Fluorometric deoxyribonucleic acid- deoxyribonucleic acid hybridization in microdilution wells as an alternative to membrane filter hybridization in which radioisotopes are used to determine genetic relatedness among bacterial strains. Int J Syst Bacteriol 39, 224-229.

Felsenstein, J. (1989). PHYLIP - Phylogeny inference package (version 3.2). Cladistics 5, 164-166.

Jukes, T. H. \& Cantor, C. R. (1969). Evolution of protein molecules. In Mammalian Protein Metabolism, pp. 21-132. Edited by H. N. Munro. New York: Academic Press.

Kämpfer, P., Denner, E. B. M., Meyer, S., Moore, E. R. B. \& Busse, H.-J. (1997). Classification of "Pseudomonas azotocolligans" Anderson 1955, 132, in the genus Sphingomonas as Sphingomonas trueperi sp. nov. Int J Syst Bacteriol 47, 577-583.

Leifson, E. (1963). Determination of carbohydrate metabolism of marine bacteria. J Bacteriol 85, 1183-1184.

Marmur, J. \& Doty, P. (1962). Determination of the base composition of deoxyribonucleic acid from its thermal denaturation temperature. $J$ Mol Biol 5, 109-118.

Owen, R. J., Hill, L. R. \& Lapage, S. P. (1969). Determination of DNA base compositions from melting profiles in dilute buffers. Biopolymers 7, 503-516.

Pearson, W. R. \& Lipman, D. J. (1988). Improved tools for biological sequence comparison. Proc Natl Acad Sci U S A 85, 2444-2448.

Romanenko, L. A., Uchino, M., Mikhailov, V. V., Zhukova, N. V. \& Uchimura, T. (2003). Marinomonas primoryensis sp. nov., a novel psychrophile isolated from coastal sea-ice in the Sea of Japan. Int J Syst Evol Microbiol 53, 829-832.

Romanenko, L. A., Uchino, M., Falsen, E., Lysenko, A. M., Zhukova, N. V. \& Mikhailov, V. V. (2005). Pseudomonas xanthomarina sp. nov., a novel bacterium isolated from marine ascidian. J Gen Appl Microbiol 51, 65-71.

Rowe, N. J., Tunstall, J., Galbraith, L. \& Wilkinson, S. G. (2000). Lipid composition and taxonomy of [Pseudomonas] echinoides: transfer to the genus Sphingomonas. Microbiology 146, 3007-3012.

Saitou, N. \& Nei, M. (1987). The neighbor-joining method: a new method for reconstructing phylogenetic trees. Mol Biol Evol 4, 406-425.

Shida, O., Takagi, H., Kadowaki, K., Nakamura, L. K. \& Komagata, K. (1997). Transfer of Bacillus alginolyticus, Bacillus chondroitinus, Bacillus curdlanolyticus, Bacillus glucanolyticus, Bacillus kobensis, and Bacillus thiaminolyticus to the genus Paenibacillus and emended description of the genus Paenibacillus. Int J Syst Bacteriol 47, 289-298.

Smibert, R. M. \& Krieg, N. R. (1994). Phenotypic characterization. In Methods for General and Molecular Bacteriology, pp. 607-655. Edited by P. Gerhardt, R. G. E. Murray, W. A. Wood \& N. R. Krieg. Washington, DC: American Society for Microbiology. 
Stackebrandt, E. \& Goebel, B. M. (1994). Taxonomic note: a place for DNA-DNA reassociation and 16S rRNA sequence analysis in the present species definition in bacteriology. Int J Syst Bacteriol 44, 846-849.

Sugawara, H., Tanaka, N. \& Miyazaki, S. (2003). An e-Workbench for the study of microbial diversity: the system design and basic functions. Microbiol Cult Coll 19, 59-67.

Takeuchi, M., Hamana, K. \& Hiraishi, A. (2001). Proposal of the genus Sphingomonas sensu stricto and three new genera, Sphingobium, Novosphingobium and Sphingopyxis, on the basis of phylogenetic and chemotaxonomic analyses. Int J Syst Evol Microbiol 51, 1405-1417.

Thompson, J. D., Higgins, D. G. \& Gibson, T. J. (1994). CLUSTAL W: improving the sensitivity of progressive multiple sequence alignment through sequence weighting, position-specific gap penalties and weight matrix choice. Nucleic Acids Res 22, 4673-4680.

Wayne, L. G., Brenner, D. J., Colwell, R. R., Grimont, P. A. D., Kandler, O., Krichevsky, M. I., Moore, L. H., Moore, W. E. C., Murray, R. G. E. \& other authors (1987). International Committee on Systematic Bacteriology. Report of the ad hoc committee on reconciliation of approaches to bacterial systematics. Int $J$ Syst Bacteriol 37, 463-464.
Xie, C.-H. \& Yokota, A. (2006). Sphingomonas azotifigens sp. nov., a nitrogen-fixing bacterium isolated from the roots of Oryza sativa. Int J Syst Evol Microbiol 56, 889-893.

Yabuuchi, E., Yano, I., Oyaizu, H., Hashimoto, Y., Ezaki, T. \& Yamamoto, H. (1990). Proposals of Sphingomonas paucimobilis gen. nov. and comb. nov., Sphingomonas parapaucimobilis sp. nov., Sphingomonas yanoikuyae sp. nov., Sphingomonas adhaesiva sp. nov., Sphingomonas capsulata comb. nov., and two genospecies of the genus Sphingomonas. Microbiol Immunol 34, 99-119.

Yabuuchi, E., Kosako, Y., Fujiwara, N., Naka, T., Matsunaga, I., Ogura, H. \& Kobayashi, K. (2002). Emendation of the genus Sphingomonas Yabuuchi et al., 1990 and junior objective synonymy of the species of three genera, Sphingobium, Novosphingobium and Sphingopyxis, in conjunction with Blastomonas ursincola. Int J Syst Evol Microbiol 52, 1485-1496.

Yamaguchi, T., Kobayashi, Y., Adachi, K. \& Imamura, N. (2003). Argimicins B and C, new anti-cyanobacterial compounds produced by Sphingomonas sp. M-17. J Antibiot 56, 655-657.

Yoon, J.-H., Lee, M.-H., Kang, S.-J., Lee, S.-Y. \& Oh, T.-K. (2006). Sphingomonas dokdonensis sp. nov., isolated from soil. Int J Syst Evol Microbiol 56, 2165-2169. 